\title{
IMMUNOCYTOCHEMICAL LOCALIZATION OF CATECHOL ESTROGENS IN THE RAT PITUITARY GLAND. II. MEDIAN EMINENCE ${ }^{1}$
}

\author{
Katsuhiro INOUE and Itsuo YOSHIZAWA* \\ Department of Oral Anatomy, Okayama University Dental School, Okayama 700, \\ and Hokkaido Institute of Pharmaceutical Sciences*, Otaru 047
}

Received for publication December 15, 1988 and in revised form February 15, 1989

\begin{abstract}
Light and electron microscopic immunocytochemical observations of catechol estrogens in the median eminence of the rat were made using a specific antibody raised against 2-hydroxyestrone coupled to bovine serum albumin and the peroxidase-antiperoxidase technique. Immunoreactive deposits were found in the tanycytes and glia cells. The terminal processes of the reactive cells ended in the perivascular space. Catechol estrogen can cause elevation and/or suppression of serum levels of luteinizing hormone (LH). Thus, our results suggest that catechol estrogens in the reactive cells may be involved in the regulation of secretion of luteinizing hormone releasing hormone (LHRH) in the median eminence.
\end{abstract}

Catechol estrogens are the end products of the biotransformation of estrogen in man and rat. Parvizi and Ellendorff (40) initially demonstrated the action of catechol estrogens by showing that the secretion of luteinizing hormone (LH) by the anterior pituitary is inhibited by microinjection of 2-hydroxyestradiol $\left(2-\mathrm{OHE}_{2}\right)$ in the amygdala of the miniature pig. They mentioned that it remained to be established whether 2-OHE $\mathrm{OH}_{2}$ can cross the blood-brain barrier or whether it is synthesized in the brain, or both. Subsequently, several authors reported that estrogens are hydroxylated to become catechol estrogens in the brain as well as in the liver $(2,12,13,42)$. The arcuatemedian eminence region, in particular, contained the highest levels of activity of estrogen 2,4-hydroxylase in rat brain (56). Furthermore, the metabolic clearance rate of catechol estrogens in the bloodstream is very high (28). Consequently, catechol estrogens in the bloodstream are assumed not to produce any local effects in the brain. Despite much speculation, the mechanism of the action of catechol estrogens in the brain remains unknown. The specific localization of catechol estrogens might give further clues to their function. We have already reported that the localization of catechol estrogens can be determined by immunocytochemical methods $(19,20)$. In the present study we examined the distribution of catechol estrogens in the median eminence of the rat. The tanycytes and the glia cells in median eminence were all found to contain catechol estrogens.

\footnotetext{
1 Part II of a series entitled "Immunocytochemical localization of catechol estrogens in the rat pituitary gland”. Part I can be found in the Acta histochem. cytochem. 19; 767, 1986.
} 


\section{MATERIALS AND METHODS}

Eleven male rats (8-13 weeks old) of the Wistar strain were anesthetized with Nembutal and perfused through the heart with $100 \mathrm{ml}$ of a mixture of $0.25 \%$ glutaraldehyde and $4 \%$ paraformaldehyde in $0.1 \mathrm{M}$ phosphate buffer, $\mathrm{pH} 7.4$, for 10 min. After perfusion, the median eminences were rapidly removed and immersed for two days in a buffered solution of picric acid-formaldehyde (PAF) (50). Tissues were rinsed overnight with $0.01 \mathrm{M}$ phosphate-buffered saline (PBS, pH 7.4) at $4^{\circ} \mathrm{C}$ after fixation. Frozen sections $(20 \sim 35 \mu \mathrm{m})$ of these tissues were cut on a Sakura Coldtome (Sakura, Japan) and collected in PBS. In an attempt to minimize the formation of ice crystals and associated artifacts, fixed blocks were treated by immersion in $20 \%$ glycerin in PBS for 15 min prior to freezing. The sections were treated with $0.005 \mathrm{M}$ unbuffered periodic acid and $0.003 \mathrm{M}$ unbuffered sodium borohydride to inhibit endogenous peroxidase activity (22). They were subsequently incubated with a 1:50 dilution of normal goat serum in PBS for $30 \mathrm{~min}$ at room temperature.

Sections were incubated for $24 \mathrm{hr}$ at $4^{\circ} \mathrm{C}$ in a 1:2000 dilution (in PBS) of either rabbit antiserum (for details see reference 19) raised against 2-hydroxyestrone-17-(Ocarboxymethyl)-oxime-bovine serum albumin (BSA) conjugate, which was absorbed with BSA or, as a control, with diluted antiserum which had been absorbed with BSA and 2-hydroxyestrone. Then sections were incubated in a 1:500 dilution (in PBS) of goat anti-rabbit IgG (Cappel Laboratories, U.S.A.) for $30 \mathrm{~min}$; and finally in a 1:500 dilution (in PBS) of peroxidase-antiperoxidase complex (PAP) (Cappel Laboratores) for $30 \mathrm{~min}$ at room temperature. All sections were washed for $15 \mathrm{~min}$ each in three changes of PBS between each step. The product of the peroxidase reaction was developed by incubation of sections for $5 \mathrm{~min}$ in $3,3^{\prime}$-diaminobenzidine $(0.05 \%)$ in $0.05 \mathrm{M}$ Tris buffer, $\mathrm{pH} 7.6$, that contained $0.01 \% \mathrm{H}_{2} \mathrm{O}_{2}$. The peroxidase reaction was terminated by exposure of sections to $0.1 \mathrm{M}$ cacodylate buffer, $\mathrm{pH} 7.4$, at $4^{\circ} \mathrm{C}$, overnight. Sections were postfixed for one hour at room temperature in $1 \% \mathrm{OsO}_{4}$ in $0.1 \mathrm{M}$ cacodylate buffer, dehydrated in a graded series of alcohol and propylene oxide, and embedded in Epon. Ultrathin sections were cut on a Sorvall microtome (MT 5000) and examined under a Hitachi H-800 electron microscope.

\section{RESULTS}

Immunocytochemical localization of catechol estrogens was achieved in the median eminence of the rats. Ependymal tanycytes and glia cells exhibited reaction products specific for catechol estrogens (Figs. 1, 3). As shown in Fig. 2, no evidence of

FIG. 1. One- $\mu$ m-thick transverse section of the rat median eminence incubated with catecholestrogen-specific antibodies absorbed with BSA. The tanycytes (arrowheads) and their processes (arrows) contain catechol estrogen. III: Third ventricle. $\times 440$

FIG. 2. Control preparation of the rat median eminence treated with catechol-estrogen-specific antibodies in serum absorbed with BSA and 2-hydroxyestrone. No staining for catechol estrogens is seen. III: Third ventricle. $\times 440$

FIG. 3. One- $\mu$ m-thick transverse section of the rat median eminence. A glia cell (arrowhead) which is immunopositive for catechol estrogen is seen. III: Third ventricle. C: Capillary lumen in the external layer. $\times 830$

FIG. 4. A tanycyte (T), located in the ependymal lining, contains catechol estrogens. III: Third ventricle. E: Ependymal cell. $\times 5,600$ 


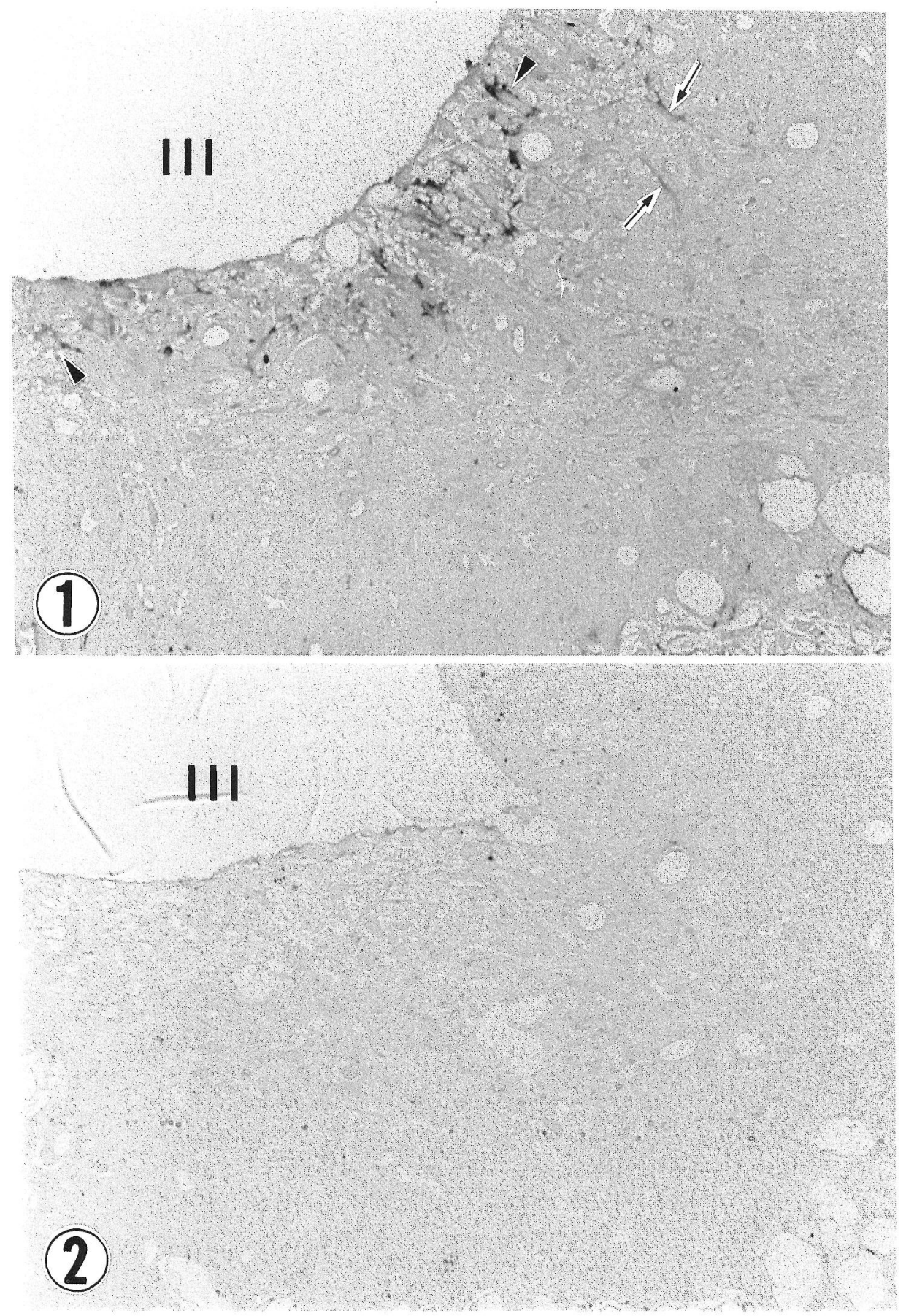



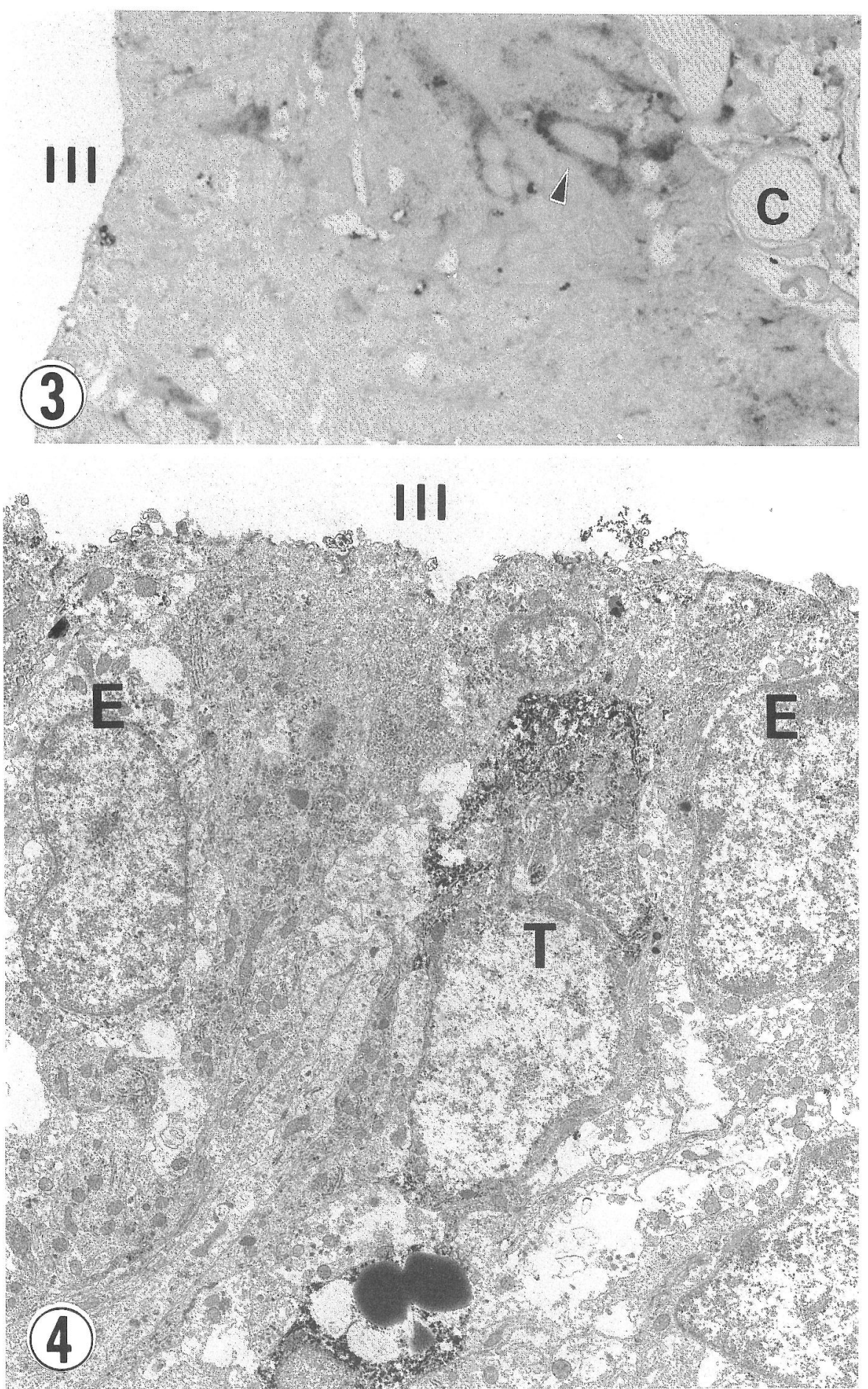

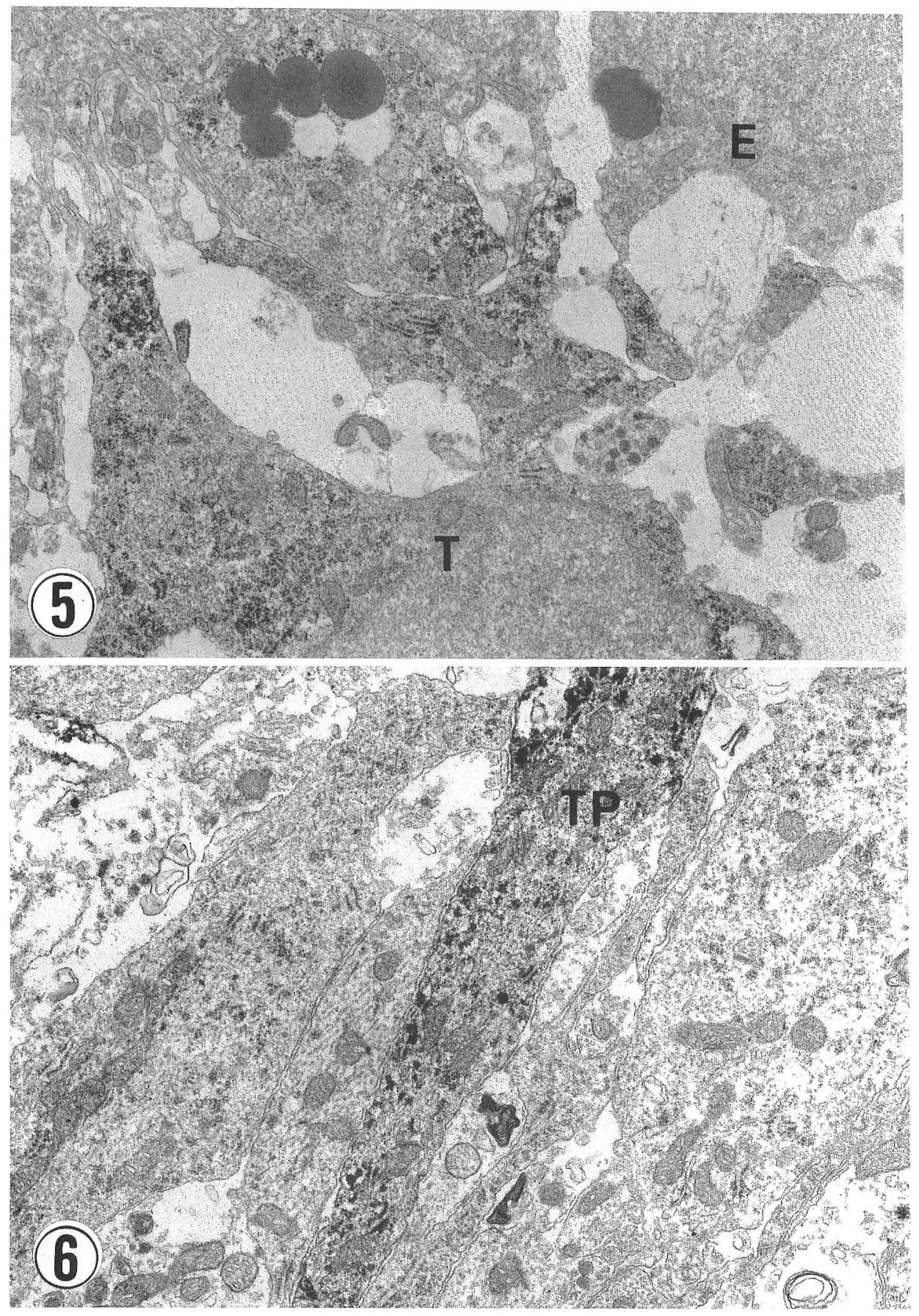

FIG. 5. At the floor of the third ventricle, a tanycyte positive for catechol estrogen (T) is located beneath ependymal cells $(\mathrm{E}) . \times 13,000$

FIG. 6. The long process (TP) of a tanycyte that is positive for catechol estrogens is seen in the internal layer of the rat median eminence. $\times 13,000$ 


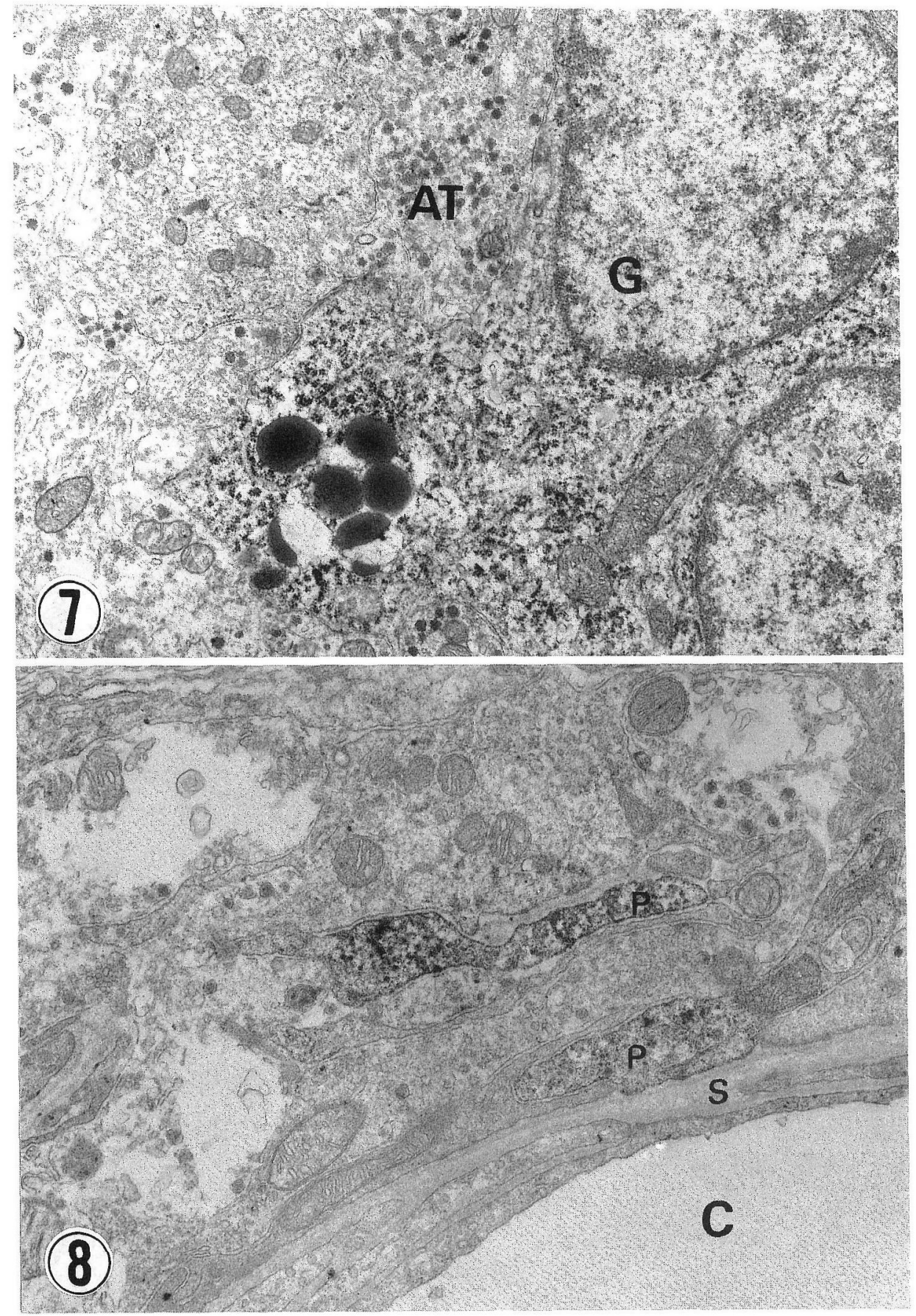

FIG. 7. A glia cell $(\mathrm{G})$ in the internal layer of the rat median eminence contains catechol estrogens. AT: Axon terminal. $\times 13,000$

FIG. 8. In the internal layer of the rat median eminence, a catechol-estrogen-positive process $(\mathrm{P})$ of a reactive cell is seen adjacent to the perivascular space $(S) . \quad C$ : Capillary lumen. $\quad \times 20,000$ 


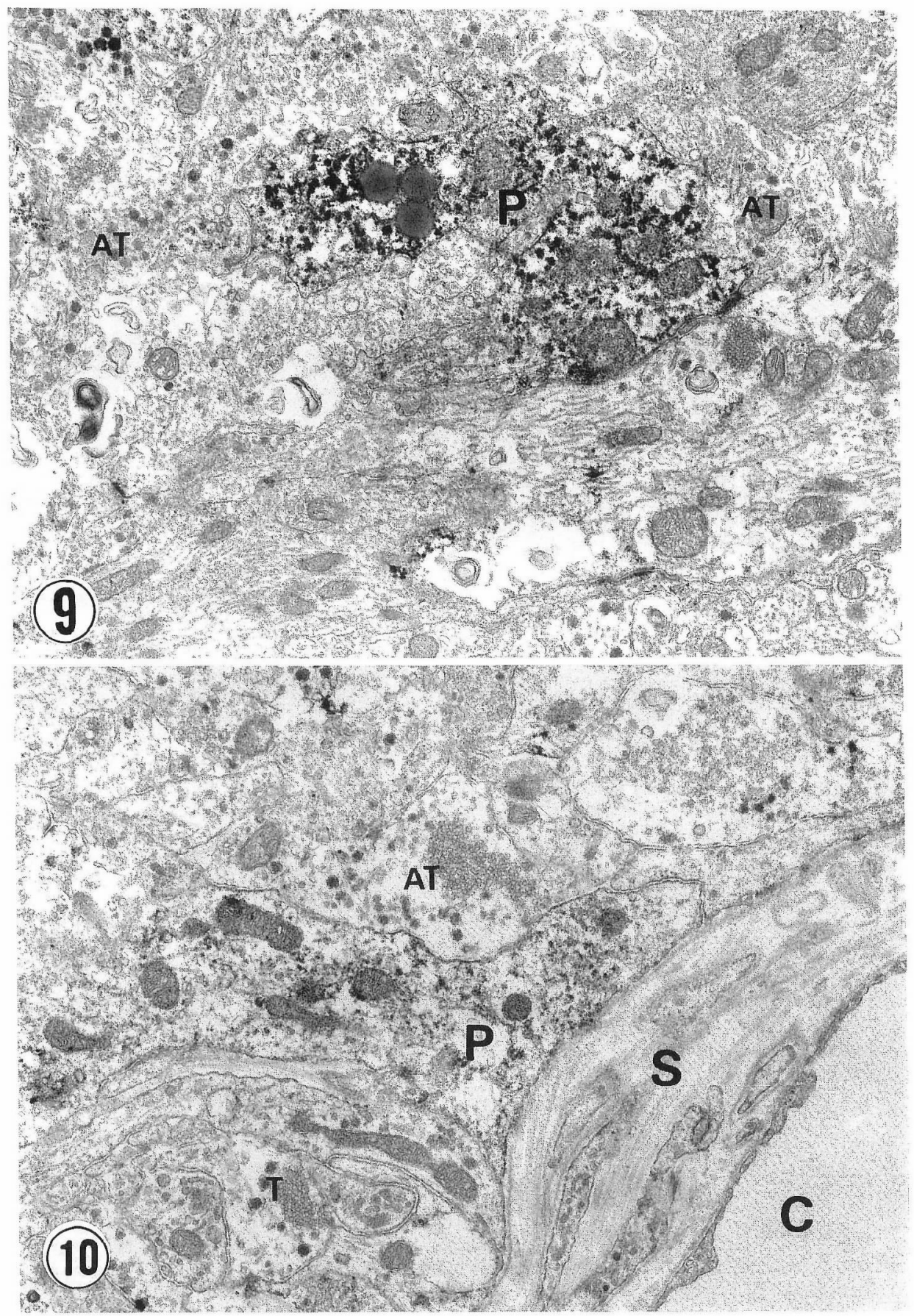

FIG. 9. A catechol-estrogen-positive process $(\mathrm{P})$ of a reactive cell in the external layer of the rat median eminence. A few lipid droplets are visible in the process $(\mathrm{P}) . \quad \mathrm{AT}$ : axon terminal. $\times 10,000$ Fig. 10. A catechol-estrogen-positive process $(\mathrm{P})$ of a reactive cell adjacent to the perivascular space $(\mathrm{S})$ in the external layer of the rat median eminence. AT: axon terminal. $\times 15,000$ 
catechol estrogens was seen in the median eminence in control sections. At the floor of the third ventricle, the cell bodies of the tanycytes were located in the ependymal layer or beneath it (Figs. 1, 5). The glia cells were found in both the internal layer and the external layer of the median eminence (Figs. 3, 7). Reactive glia cells have the characteristic morphology of astrocytes, for example, they contain a few lipid droplets (Fig. 7).

The specific reaction products in these reactive cells were distributed diffusely throughout the cytoplasm, but they were absent from the nucleus (Figs. 4, 5, 7). The long processes of the tanycytes and astrocytes extending toward the portal capillaries were also positive for the specific reaction products (Figs. 1, 3, 4, 6). The terminal processes of the reactive cells ended in the perivascular space of the internal layer (Fig. 8) and the external layer (Fig. 10). However, it was difficult to judge from its fine structure whether the processes of the reactive cells belonged to the tanycytes or to glia cells. The processes of the reactive cells were surrounded by axon terminals containing large electron-dense granules (100-120 nm) and small electron-lucid vesicles (50$60 \mathrm{~nm}$ ) (Figs. 8, 9, 10).

\section{DISCUSSION}

Sexual dimorphism of estrogen-2-hydroxylase activity is seen in the brain of the adult rat. After sexual maturation is completed (after 6 to 8 weeks of life), estrogen-2hydroxylase activity in the male increases to a level two to five times that in the female (43). For this reason, we examined only the brains of male adult rats. The immunocytochemical evidence presented in this paper demonstrates that tanycytes and glia cells in the median eminence of the rat contain immunoreactive catechol estrogens. These results are in agreement with the previous demonstrations of the existence of biochemically detectable catechol estrogens or of estrogen-2-hydroxylase, the enzyme involved in the biosynthesis of catechol estrogens, in the hypothalamus of several animals, including the rat $(2,3,5,11,12,17,36,42,44,51,56)$. Our results suggest that catechol estrogens may be synthesized locally in the brain. However, catechol estrogens have a very low molecular weight and are both soluble and diffusible, making it easy for errors to occur in attempts to localize them. Immunocytochemical evidence of catechol estrogens in reactive cells was spread diffusely throughout the cytoplasm but was absent from the nucleus. This result suggests that, perhaps, catechol estrogens bind to certain proteins, such as globulins, which are well known to bind estrogens in the bloodstream. The biochemical observations by Nelson et al. (38), which indicate that catechol estrogens bind irreversibly to microsomal proteins, tend to support this hypothesis. Parvizi et al. (41) reported the anatomical pattern of nuclear binding of catechol estrogens in the brain, pituitary and uterus. The discrepancies between our results and those of Parvizi et al. (41) may be due to differences in methodology.

Catechol estrogens can cause elevation and/or suppression of serum levels of luteinizing hormone $(\mathrm{LH})$ and prolactin under different conditions related to age, sex, gonadal status, species, etc $(1,8,14,31,32,37,45,49,54)$. The possible involvement of catechol estrogens in the reactive cells of the median eminence in the mechanism of secretion of $\mathrm{LH}$ or prolactin presents a very interesting question. Tanycytes are thought to facilitate secretion into the capillaries of the hypophyseal portal 
system $(27,47,55)$. Thus, catechol estrogens may be secreted into the perivascular space and may then function as modulators and/or may bind to estrogen receptors in the median eminence. This hypothesis is supported by several reports that specific receptors for catechol estrogens exist in cell membranes $(10,39,46)$; an interaction between catechol estrogens and estrogen receptors has also been reported to occur in the hypothalamus $(9,26,34,40)$. Etchegoyen et al. (10) suggest that catechol estrogens may impair $\beta$-adrenocepter-mediated stimulation of adenylate cyclase in hypothalamic membranes at a post-receptor site. The nerve endings of neurons that release luteinizing hormone-releasing hormone $(\mathrm{LHRH})$ are also present in the median eminence $(6,24,25,35)$. Catechol estrogens may be capable of reaching the nerve endings of LHRH-releasing neurons in a sufficiently high concentration to produce local effects. Consequently, catechol estrogens may regulate the secretion of LHRH from LHRH-releasing neurons. However, the possibility cannot be excluded that catechol estrogens, secreted from the reactive cells in the median eminence, enter the portal vessel and become involved in the regulation of pituitary function, since catechol estrogens sensitize cultured pituitary cells to LHRH (18). In addition, catechol estrogens modulate the secretion of prolactin from the pituitary gland $(4,15$, $23,45,48)$.

It is also possible that catechol estrogens play a role as a competitor of catecholamines in the reactions catalyzed by catechol-O-methyltransferase (COMT) in the tanycytes and glia cells of the median eminence. COMT has been detected in these cells by immunocytochemical methods (our unpublished observations). Breuer et al. (8) have shown that catechol estrogens have an effect on COMT activity in the median eminence. Catechol estrogens are good inhibitors of COMT activity in the brain $(7,29,30,31,33)$ and may prolong the response of tissues to catecholamines (16). However, the relatively high affinity of COMT for catechol estrogens and the present evidence for the presence of both the substrate and the catabolic enzyme in the same cell strongly suggest a role for COMT in the local metabolic control of catechol estrogens. We have also demonstrated the coexistence of catechol estrogens and COMT in the duct cells of the parotid gland of the rat (21).

Finally, the catechol-estrogen-positive glia cells in the median eminence correspond to the astrocytic tanycyte described by Zaborsky and Schieble (57). Since these cells possess the structural features of tanycytes as well as of astrocytes, they probably have the same function as tanycytes. Our present results provide additional evidence for multiple functions of tanycytes and glia cells in the median eminence.

\section{REFERENCES}

1. Ball, P., Emons, G., Klingebiel, T., Grühn, K.-M. and Knuppen, R.: Effects of catecholestrogens on luteinizing hormone levels in long term ovariectomized adult rats. Endocrinology 109; 1037-1039, 1981.

2. Ball, P., Haupt, M. and Knuppen, R.: Comparative studies on the metabolism of oestradiol in the brain, the pituitary and the liver of the rat. Acta Endocr. 87; 1-11, 1978.

3. Ball, P. and Knuppen, R.: Formation of 2- and 4-hydroxyestrogens by brain, pituitary, and liver of the human fetus. J. Clin. Endocrinol. Metab. 47; 732-737, 1978.

4. Banks, P. K., Inkster, S. E., White, N. and Jeffcoate, S. L.: 2-hydroxyoestradiol acutely inhibits prolactin secretion from the superfused pituitary glands of normal female rats: evidence for a cyclical effect. J. Endocr. 111; 199-204, 1986. 
5. Barbieri, R. L., Canick, J. A. and Ryan, K. J.: Estrogen 2-hydroxylase: Activity in rat tissues. Steroids 32; 529-538, 1978.

6. Barry, J.: Immunohistochemistry of luteinizing hormone-releasing hormone-producing neurons of the vertebrates. Internat. Rev. Cytol. 60; 179-221, 1979.

7. Breuer, H. and Köster, G.: Interaction between oestrogens and neurotransmitters at the hypophysial-hypothalamic level. J. Steroid. Biochem. 5; 961-967, 1974.

8. Breuer, H., Schneider, H. T., Doberauer, C., Grüter, S. and Ladosky, W.: Effects of oestradiol-17 $\beta$ and 2-hydroxy-oestradiol-17 $\beta$ on LH-concentration in plasma and COMT activities in hypothalamic nuclei of rats. Exp. Brain Res. Suppl. 3; 118-129, 1981.

9. Davies, I. J., Naftolin, F., Ryan, K. J., Fishman, J. and Siu, J.: The affinity of catechol estrogens for estrogen receptors in the pituitary and anterior hypothalamus of the rat. Endocrinology 97; 554-557, 1975.

10. Etchegoyen, G. S., Cardinali, D. P., Pérez, A., Tamayo, J. and Pérez-Palacios, G.: Binding and effects of catecholestrogens on adenylate cyclase activity, and adrenoceptors, benzodiazepine and GABA receptors in guinea-pig hypothalamic membranes. Europ. J. Pharmacol. 129; 1-10, 1986.

11. Fishman, J., Naftolin, F., Davies, I. J., Ryan, K. J. and Petro, Z.: Catechol estrogen formation by the human fetal brain and pituitary. J. Clin. Endocrinol. Metab. 42; 177-180, 1976.

12. Fishman, J. and Norton, B.: Catechol estrogen formation in the central nervous system of the rat. Endocrinology 96; 1054-1059, 1975.

13. Fishman, J. and Norton, B.: Specific and nonspecific components in the oxidative metabolism of estradiol by the male rat brain in vitro. J. Steroid Biochem. 19; 219-228, 1983.

14. Fishman, J., Norton, B. I. and Krey, L.: 2-hydroxylation of estrogens in the brain participates in the initiation of the preovulatory LH surge in the rat. Biochem. Biophys. Res. Comm. 93; 471$477,1980$.

15. Fishman, J. and Tulchinsky, D.: Suppression of prolactin secretion in normal young women by 2-hydroxyestrone. Science 210; 73-74, 1980.

16. Ghraf, R. and Hienke, C.: Interaction of catechol estrogens with catecholamine synthesis and metabolism. In Catechol Estrogens, ed. by G. R. Merriam and M. B. Lipsett, Raven Press, New York, 1983, p. 177-187.

17. Hersey, R. M., Gunsalus, P., Lloyd, T. and Weisz, J.: Catechol estrogen formation by brain tissue: A comparison of the release of tritium from $\left[2{ }^{3} \mathrm{H}\right]$ estradiol with $\left[6,7-{ }^{3} \mathrm{H}\right] 2$-hydroxyestradiol formation from $\left[6,7-{ }^{3} \mathrm{H}\right]$ estradiol by rabbit hypothalami in vitro. Endocrinology 109; 1902-1911, 1981.

18. Hsueh, A. J. W., Erickson, G. F. and Yen, S. S. C.: The sensitizing effect of estrogens and catechol estrogen on cultured pituitary cells to luteinizing hormone-releasing hormone: Its antagonism by progestins. Endocrinology 104; 807-813, 1979.

19. Inoue, K. and Yoshizawa, I.: Immunocytochemical localization of catechol-estrogen in the rat liver after using various fixatives. Acta histochem. cytochem. 18; 597-603, 1985.

20. Inoue, K. and Yoshizawa, I.: Immunocytochemical localization of catechol-estrogen in the rat pituitary gland. I. Posterior lobe. Acta histochem. cytochem. 19; 767-774, 1986.

21. Inoue, K., Yoshizawa, I. and Creveling, C. R.: Immunocytochemical evidence for the coexistence of catecholestrogen and catechol-O-methyltransferase in the rat parotid gland. J. Dent. Res. 66; 1627-1629, 1987.

22. Isobe, Y., Chen, S. T., Nakane, P. K. and Brown, W. R.: Studies on translocation of immunoglobulins across intestinal epithelium. I. Improvements in the peroxidase-labeled antibody method for application to study of human intestinal mucosa. Acta histochem. cytochem. 10; 161-171, 1977.

23. Jellick, P. H. and Shin, S. H.: Effect of catechol estrogens on prolactin secretion in the rat: Lack of correlation with estrogenic activity. Neuroendocrinology 45; 99-103, 1987.

24. Kawano, H. and Daikoku, S.: Immunohistochemical demonstration of LHRH neurons and their pathways in the rat hypothalamus. Neuroendocrinology 32; 179-186, 1981. 
25. Kawano, H., Watanabe, Y. G. and Daikoku, S.: Light and electron microscopic observation on the appearance of immunoreactive LHRH in perinatal rat hypothalamus, Cell Tissue Res. 213; 465-474, 1980.

26. Kirchhoff, J., Hornung, E., Ghraf, R., Ball, P. and Knuppen, R.: Interactions of catecholestrogens with cytoplasmic and nuclear estrogen receptors in rat pituitary gland and hypothalamus. J. Neurochem. 37;1540-1547; 1981.

27. Kobayashi, H., Matsui, T. and Ishii, S.: Functional electron microscopy of the hypothalamic median eminence. Internat. Rev. Cytol. 29; 281-381, 1970.

28. Kono, S., Brandon, D., Merriam, G. R., Loriaux, D. L. and Lipsett, M. B.: Low plasma levels of 2-hydroxyestrone are consistent with its rapid metabolic clearance. Steroids 36; 463$472,1980$.

29. Köster, G. and Breuer, H.: Effect of oestradiol-17 $\beta$ on the metabolism of noradrenaline in brain slices of ovariectomized rats. Acta Endocr. 98; 1-7, 1981.

30. Köster, G., Breuer, H. and Schneider, H. Th.: Effect of 2-substituted oestrogens in vivo on the metabolism of noradrenaline in rat brain. Acta Endocr. 99; 1-8, 1982.

31. Ladosky, W., Azambuja, H. M. C. and Schneider, H. Th.: Possible mechanism of action of 2-hydroxylated estradiol on the positive feedback control for $\mathrm{LH}$ release in the rat. J. Steroid Biochem. 19; 639-644, 1983.

32. Lamberts, S. W. J., Nagy, I., Uitterlinden, P. and MacLeod, R. M.: The effect of catecholestrogens on the growth of prolactin-secreting pituitary tumors and normal prolactin synthesis in the rat. Endocrinology 110; 1141-1146, 1982.

33. Lloyd, T., Weisz, J. and Breakefield, X. O.: The catechol estrogen, 2-hydroxyestradiol, inhibits catechol-O-methyltransferase activity in neuroblastoma cells. J. Neurochem. 31; 245-250, 1978.

34. MacLusky, N. J., Barnea, E. R., Clark, C. R. and Naftolin, F.: Catechol estrogens and estrogen receptors. In Catechol Estrogens, ed. by G. R. Merriam and M. B. Lipsett, Raven Press, New York. 1983, p. 151-165.

35. Merchenthaler, I., Kovács, G., Lovász, G. and Sétáló, G.: The preoptico-infundibular LHRH tract of the rat. Brain Res. 198; 63-74, 1980.

36. Mondschein, J. S., Hersey, R. M. and Weisz, J.: Purification and characterization of estrogen-2/4-hydroxylase activity from rabbit hypothalami: Peroxidase-mediated catechol estrogen formation. Endocrinology 119; 1105-1112, 1986.

37. Naftolin, F., Morishita, H., Davies, I. J., Todd, R. and Ryan, K. J.; 2-hydroxyestrone induced rise in serum luteinizing hormone in the immature male rat. Biochem. Biophys. Res. Comm. 64; 905-910, 1975.

38. Nelson, S. D., Mitchell, J. R., Dybing, E. and Sasame, H. A.: Cytochrome P-450-mediated oxidation of 2-hydroxyestrogens to reactive intermediates. Biochem. Biophys. Res. Comm. 70; 1157-1165, 1976.

39. Paden, C. M., McEwen, B. S. and Fishman, J.: Binding of catechol estrogens to cell membranes. In Catechol Estrogens, ed. by G. R. Merriam and M. B. Lipsett, Raven Press, New York, 1983, p. 189-201.

40. Parvizi, N. and Ellendorff, F.: 2-hydroxy-oestradiol-17 $\beta$ as a possible link in steroid brain interaction. Nature 256: 59-60, 1975.

41. Parvizi, N., Sar, M., Duncan, G. E. and Stumpf, W. E.: Autoradiographic determination of catechol estrogen binding sites in brain, pituitary and uterus. Brain Res. 344; 373-376, 1985.

42. Paul, S. M. and Axelrod, J.: Catechol estrogens: Presence in brain and endocrine tissue. Science 197; 657-659, 1977.

43. Poth, M. A., Axelrod, J. and Hoffman, A. R.: Estrogen-2-hydroxylase: developmental, hormonal, and pharmacologic studies using a radioenzymatic method. In Catechol Estrogens, ed. by G. R. Merriam and M. B. Lipsett, Raven Press, New York, 1983, p. 19-30.

44. Reddy, V. V. R., Rajan, R. and Daly, M. J.: Oestrogen metabolism in adult rat's brain. Acta Endocrinol. 96; 7-14, 1981. 
45. Rodriguez-Sierra, J. F. and Blake, C. A.: Catecholestrogens and release of anterior pituitary gland hormones. I. Luteinizing hormone. Endocrinology 110; 318-324, 1982.

46. Schaeffer, J. M. and Hsueh, A. J. W.: 2-hydroxyestradiol interaction with dopamine receptor binding in rat anterior pituitary. J. Biol. Chem. 254; 5606-5608, 1979.

47. Scott, D. E., Dudley, G. K. and Knigge, K. M.: The ventricular system in neuroendocrine mechanisms. II. In vivo monoamine transport by ependyma of the median eminence. Cell Tissue Res. 154; 1-16, 1974.

48. Shin, S. H., Bates, L. and Jellinck, P. H.: Temporal and other effects of catechol estrogens on prolactin secretion in the rat. Neuroendocrinology 33; 352-357, 1981.

49. Shupnik, M. A., Klibanski, A., Longcope, C. and Ridgway, E. C.: Catecholestrogen regulation of prolactin synthesis in pituitary cell culture. Endocrinology 117; 939-946, 1985.

50. Stefanini, M., De Martino, C. and Zamboni, L.: Fixation of ejaculated spermatozoa for electron microscopy. Nature 216; 173-174, 1967.

51. Theron, C. N., Russell, V. A. and Taljaard, J. J. F.: Evidence that estradiol-2/4-hydroxylase activities in rat hypothalamus and hippocampus differ qualitatively and involve multiple forms of p-450: Ontogenetic and inhibition studies. J. Steroid Biochem. 23; 919-927, 1985.

52. Ugrumov, M. V. and Mitskevich, M. S.: The adsorptive and transport capacity of tanycytes during the perinatal period of the rat. Cell Tissue Res. 211; 493-501, 1980.

53. Van Leeuwen, F. W., De Raay, C., Swaab, D. F. and Fisser B.: The localization of oxytocin, vasopressin, somatostatin and luteinizing hormone releasing hormone in the rat neurohypophysis. Cell Tissue Res. 202; 189-201, 1979.

54. Villard, M.-F., Ladosky, W., Janots, D., Lenoir, V., Adeline, J., Kerdelhue, B. and Scholler, R.: Inhibition of the preovulatory LH surge after a catecholestrogen (2-hydroxyestrone) antiserum injection in the third ventricle of cycling female rats. Neuroscience Letters 78; 187-192, 1987.

55. Wagner, H. J. and Pilgrim, Ch.: Extracellular and transcellular transport of horseradish peroxidase (HRP) through the hypothalamic tanycyte ependyma. Cell Tissue Res. 152; 477$491,1974$.

56. Weisz, J. and Crowley, W. R.: Catechol estrogen formation by the CNS: Reginal distribution of estrogen-2/4-hydroxylase activity in rat brain. Neuroendocrinology 43; 543-549, 1986.

57. Záborszky, L. and Schiebler, T. H.: Übe die Glia der Eminentia mediana. Elektronenmikroskopische Untersuchungen an normalen, adrenalektomierten und kastrierten Ratten. $Z$. mikrosk.-anat. Forsch. 92; 781-799, 1978. 